\title{
Pleural empyema caused by lung hamartoma
}

\author{
Jarosław Religioni, Tadeusz Orłowski \\ Klinika Chirurgii, Instytut Gruźlicy i Chorób Płuc, Warszawa \\ Kardiochirurgia i Torakochirurgia Polska 2013; 10 (1): 67-71
}

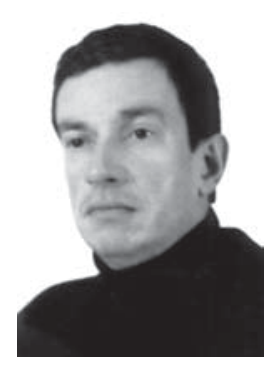

\begin{abstract}
We present a case of a 59-year-old patient with a tumor of the left lung and concomitant empyema. Ultimately, we established that the cause of the disease was a giant hamartoma, which had been left untreated for years and had infiltrated the pleural cavity. The surgery enabled a positive final outcome to be achieved.
\end{abstract}

Key words: pleural empyema, lung tumors.

\section{Introduction}

Diseases of the pleural cavity are often characterized by their non-specific course, which poses diagnostic problems prior to the selection of treatment. Plain film chest radiography may not be sufficient to precisely establish the etiology of the disease. In such cases, computed tomography is helpful in providing a specific diagnosis. Moreover, the standard procedure employed in cases of pleural effusion (puncture and potential drainage) often facilitates the establishment of a precise diagnosis. However, problems arise when a nonstandard course of the disease, in conjunction with unclear radiological imaging, does not allow for an initial diagnosis. This, in turn, is directly reflected in the treatment strategy.

\section{Case study}

A 59-year-old patient, initially diagnosed with left pleural empyema, was hospitalized in the Institute of Tuberculosis and Lung Diseases.

Five years earlier, he had been treated for pleural effusion in a local clinic. Puncture was performed, which allowed for partial aspiration of the purulent fluid. Bacteriological examination did not reveal any growth of pathogenic flora. Drainage treatment was suggested due to the incomplete expansion of the lung and the nature of the fluid; however, the patient did not consent to the procedure. Improvement of the general condition was finally achieved by means of conservative treatment, which allowed for the patient to be discharged from the hospital. For the next 5 years, the pa-

\section{Streszczenie}

Opisano przypadek 59-letniego pacjenta z guzem lewego płuca i współistniejącym ropniakiem. Ostatecznie okazało się, że przyczyną choroby była nieleczona od kilkudziesięciu lat olbrzymich rozmiarów hamartoma, która przebiła się do jamy opłucnowej. Przeprowadzony zabieg chirurgiczny pozwolit na uzyskanie dobrego wyniku końcowego.

Słowa kluczowe: ropniak opłucnej, guzy płuca.

tient did not report any significant ailments, apart from decreasing exercise tolerance. Within the last few months of this period, the patient's condition deteriorated rapidly with concomitant fever and progressive dyspnea. For this reason, the patient reported once again to the local hospital. Plain film chest radiography revealed complete opacity of the left side of the thoracic cavity, which suggested the presence of fluid (Fig. 1). This was later confirmed by puncture and partial aspiration. Culture tests of the acquired samples were negative. Since radiological examination did not provide

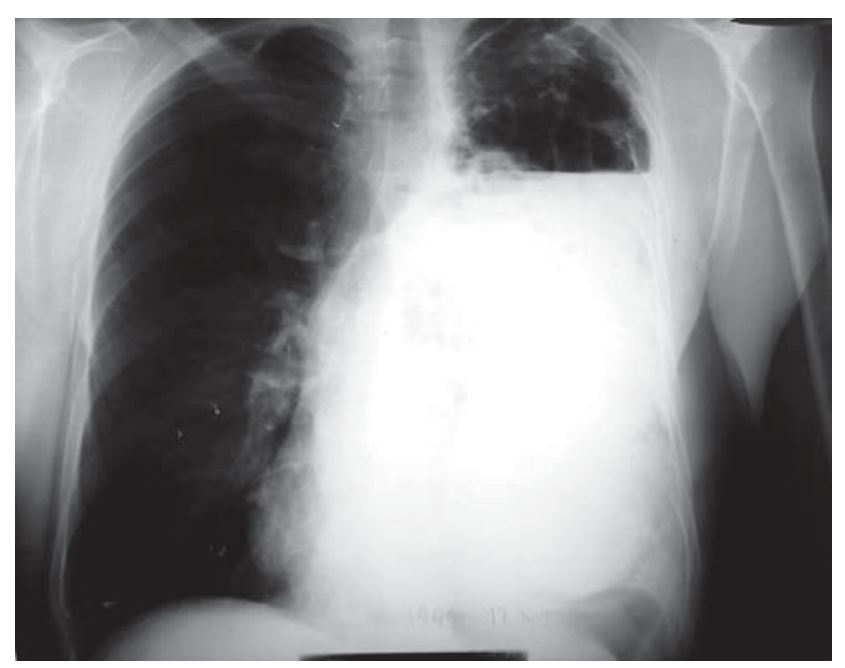

Fig. 1. Chest X-ray before hospitalization

Address for correspondence: Jarosław Religioni, Instytut Gruźlicy i Chorób Płuc, Klinika Chirurgii, ul. Płocka 26, 01-138 Warszawa, tel. +48 2243122 66, 224312 200, e-mail: j.religioni@igichp.edu.pl 
a satisfactory result, the patient was referred to our hospital. The patient arrived in a severe condition with a fever of $40^{\circ} \mathrm{C}$. Symptoms of cardiopulmonary insufficiency were diagnosed with concomitant massive swelling of the lower extremities, resting tachycardia, lowered partial oxygen pressure, and carbon dioxide accumulation. Blood tests revealed anemia with iron deficiency and hypoproteinemia. The case history indicated that the patient was receiving treatment for post-traumatic epilepsy and arterial hypertension. A drain was urgently inserted into the left pleural cavity, revealing the macroscopic presence of purulent exudate. The daily volume of aspirated fluid ranged from $4000 \mathrm{ml}$ soon after the drain was inserted to $500-1000 \mathrm{ml}$ during the following 2 weeks. Bacteriological examination did not show any growth of pathogenic flora; cytological examination of the fluid was negative. Multiple antibiotic therapy was applied because of persistent fever. However,
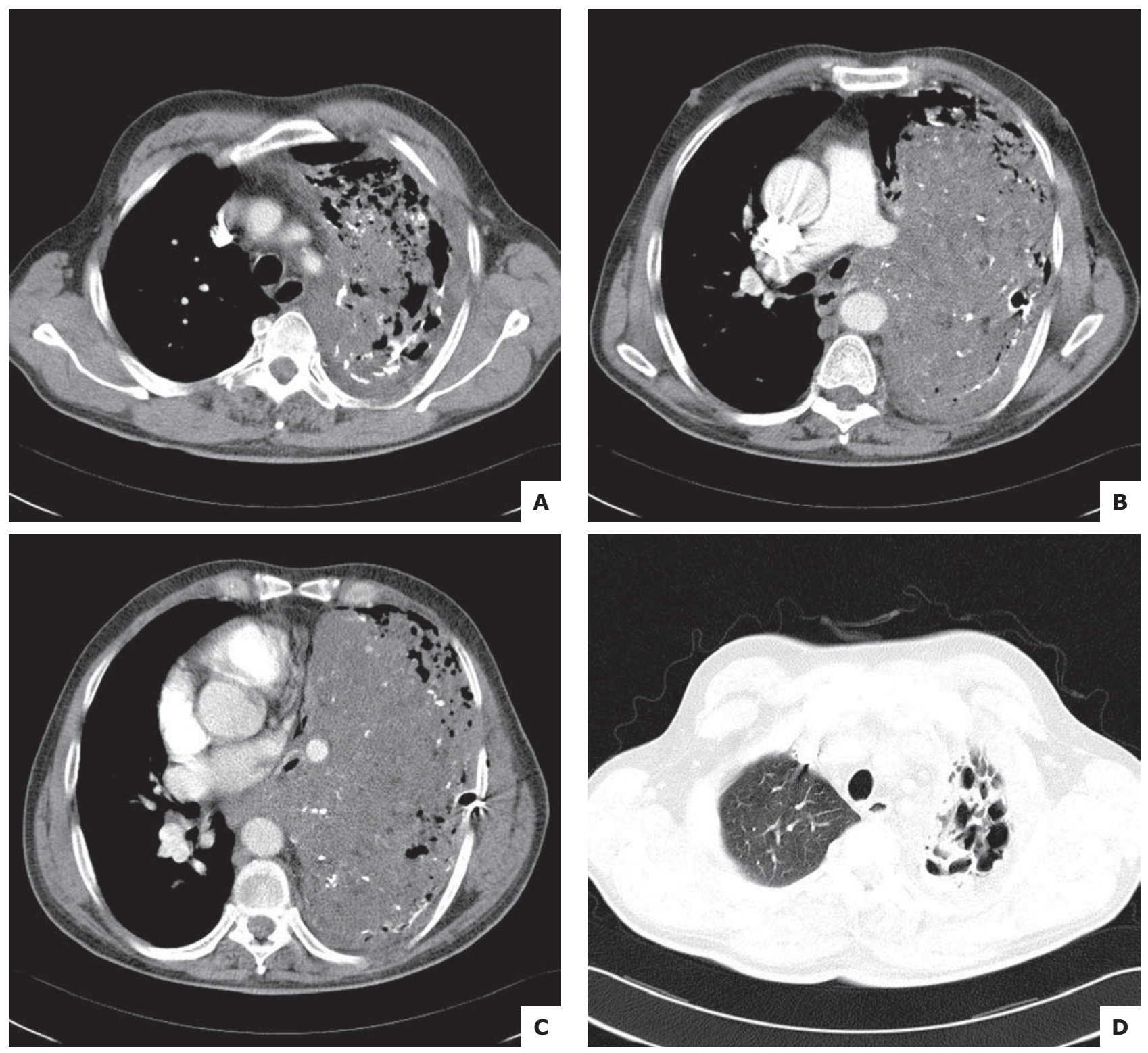

the patient's general condition did not improve significantly. Despite substantial daily drainage, the left pleural cavity remained opaque. Apart from pressure on the bronchi of the left lung, bronchoscopy did not show any other pathologies. As a result, computed tomography was conducted (Fig. $2 \mathrm{~A}-\mathrm{F})$. It revealed the presence of an extensive abnormal area of heterogeneous liquid-solid structure with numerous gas bubbles and calcifications. Small fragments of emphysematous lung parenchyma in the apex of the pleura were compressed. Pressure of similar strength was exerted on the vessels in the left lung, which were displaced to chronic empyema of unclear etiology. The drain inserted into the pleura was located inside the main lesion. Despite that, we did not manage to completely drain the cavity of the empyema. While taking medical history from the patient and his family for the second time, it was established the opposite side. Radiological imaging suggested possible

Fig. 2A-D. Chest CT scan before surgery 


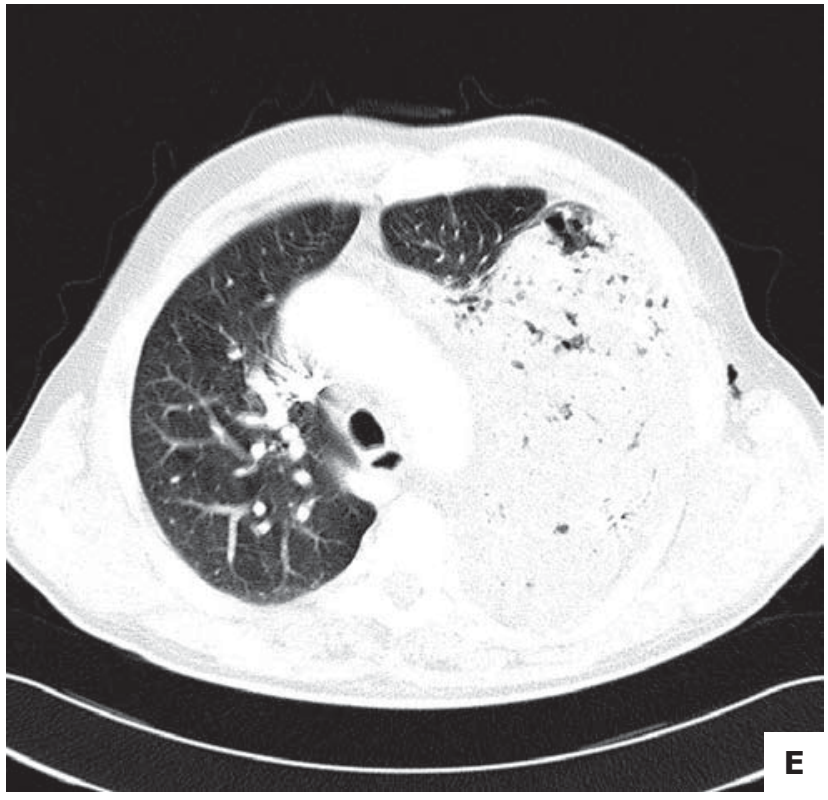

Fig. 2E-F. Chest CT scan before surgery

that the patient had been relieved from military service because of malformation of the left lung. In the context of the previous treatment failure, this information encouraged us to reassess the initial assumptions concerning the etiology of the disease. At first, we suspected that the disease was caused by a chronic suppurative process of unestablished etiology with subsequent damage to the lung parenchyma. Our current conclusion is that empyema may also be caused by undiagnosed congenital defects, such as congenital cystic lung disease, infected bronchogenic cyst, or congenital lung malformation. Since we did not manage to find an alternative treatment or achieve clinical improvement, we made the decision to perform video-assisted thoracoscopy. After the introduction of an endoscope, it was established that the purulent masses in the pleura, revealed by computed tomography, were most likely damaged lung parenchyma, as confirmed by intraoperative examination (result - necrotic masses with visible lung abscesses). This prompted us to perform a thoracotomy. It was established that the pleural cavity was filled by a giant tumor $(30 \times 25 \mathrm{~cm}$ in size), causing damage to the lung parenchyma. The narrow cavity of the empyema, into which the drain had been inserted, was located paraspinally. A decision was made to remove the lesion together with the damaged lung and the parietal pleura affected by the disease. In order to reach the hilum, an incision was made in the tumor and the necrotic masses accumulated inside were partially removed (weighing about $2.5 \mathrm{~kg}$ ). The incision line was closed with a continuous suture. These actions revealed the mediastinum and the hilum of the lung. Three pathological vessels feeding the tumor from the aorta were found; they were ligated and cut. When separating the lesion from the mediastinum, its deep penetration to the opposite side was revealed. The pulmonary artery and vessels were atrophic and narrow. Vascular staplers had to be attached, because

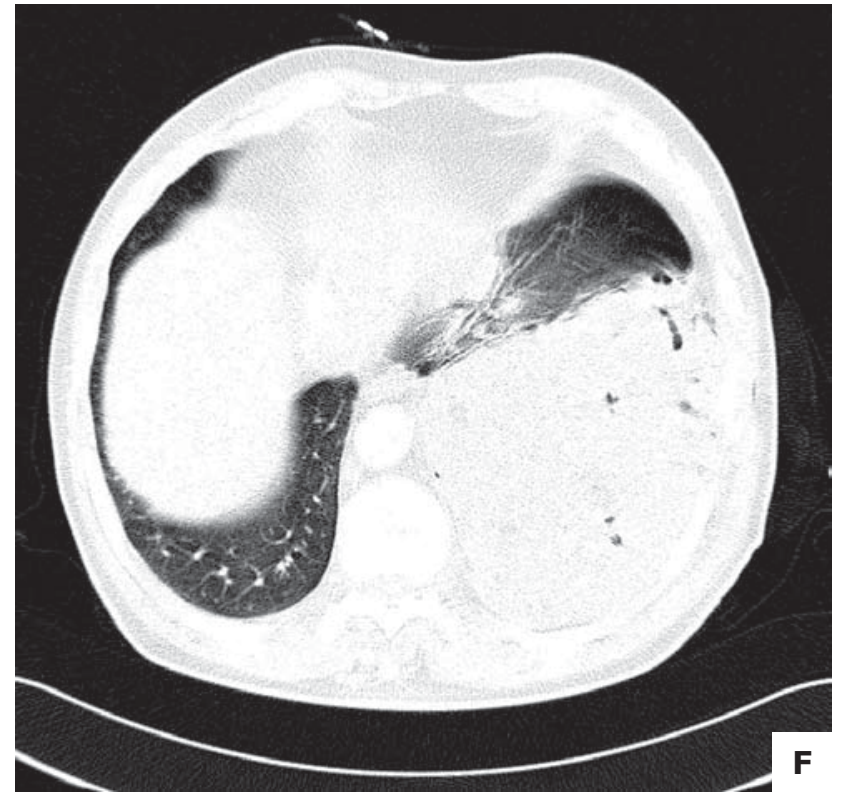

the sections which were free from infiltration were very short. The left main bronchus, which was also narrow, was stapled and cut off. Finally, pleuropneumonectomy was performed. The post-resection cavity was irrigated several times with aqueous Betadine. The chest was then closed layer by layer in a standard manner (Fig. 3). Histological examination of the preparation revealed hamartoma chondromatodes partim mesenchymale. During the postoperative period, the patient required the use of catecholamines and forced diuresis. Moreover, 2 weeks after the surgery, recurrence of the pleural empyema occurred. The presence of Klebsiella pneumoniae was found in culture tests. Consequently, a drain was reintroduced into the post-resection cavity; fenestration was performed afterwards. The daily replacement of setons led to a local decrease in inflammation. The cavity was sterilized, filled with a solution of water and antibiotics, and subsequently closed. During a six-month

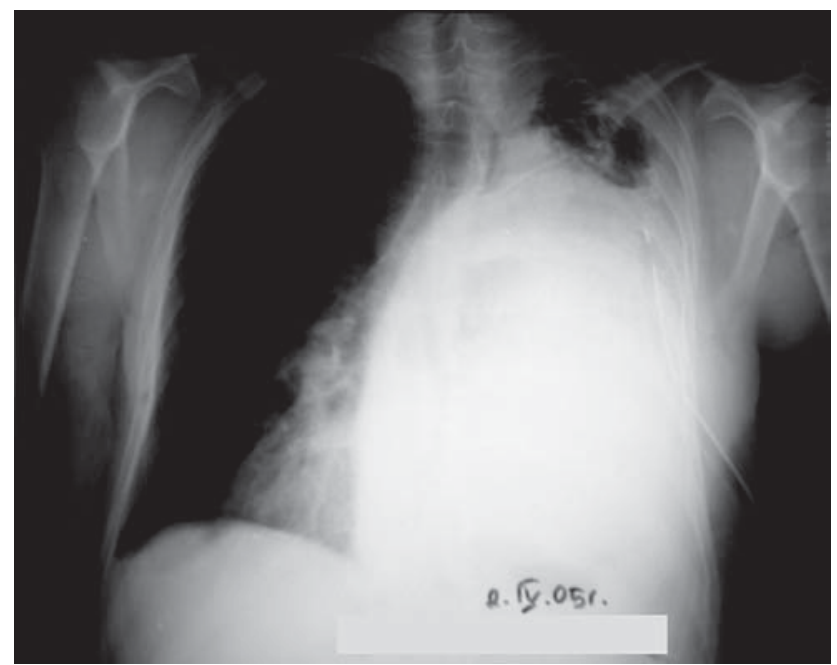

Fig. 3. Chest $\mathrm{X}$-ray after tumor and lung resection 
follow-up, we did not observe any recurrence of the empyema or other complications. One year after the surgery, recurrence of the empyema took place and additional fenestration was required. After it was closed, local stabilization was achieved. However, a year later the empyema recurred once more and thoracoplasty had to be performed. As a result, the inflammation was successfully treated (Fig. 4).

\section{Discussion}

The presented case was characterized by non-specific disease course and radiological imaging. As it was inferred from the case history, the patient had been receiving treatment for pleural effusion for 5 years. The presence of pathogenic flora in the aspirated fluid had never been established, despite its macroscopically purulent nature. The patient experienced periodic fever, and his general condition was gradually deteriorating. The clinical and radiological picture suggested empyema - hence the initial treatment, typical for this nosological entity. The general treatment strategy in the case of pleural empyema should consist of:

- diagnostic puncture - drainage and irrigation of the cavity of the empyema;

- targeted antibiotic therapy in the case of a specific pathogen, or empirical therapy if no specific pathogen is identified;

- simultaneous diagnostic imaging - ultrasonography, Xray, and, most importantly, computed tomography;

- video-assisted thoracoscopy if drainage is not effective (multilocular empyema);

- decortication of the lung in the case of fibrothorax, resulting from fibrin deposition.

In the described case, computed tomography of the chest had never been conducted before the patient's hospitalization in the Institute of Tuberculosis. Had this examination been conducted at the early stage of the disease, it might have

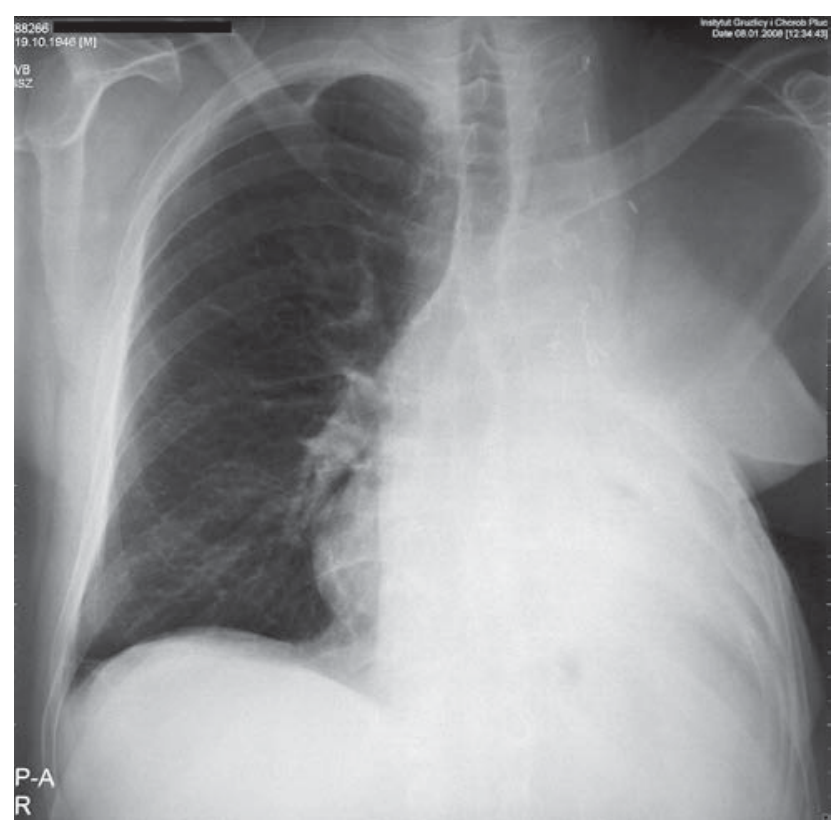

Fig. 4. Chest X-ray after thoracoplasty enabled the identification of its etiology. Later on, it was difficult to determine whether the abnormal tissue masses were located in the pleura or in the lung. As the patient's family informed us that he may have suffered from a congenital chest organ defect, we assumed that it might have been the cause of the pleural empyema. It is worth mentioning that congenital anomalies of the respiratory system are classified into 3 groups: bronchopulmonary, vascular, and mixed. The first group includes, among others: pulmonary malformation, bronchial malformation, congenital emphysematous bullae, cystic lung disease, bronchogenic cysts, anomalies in the number and branching of the bronchi, and defects of the diaphragm. The remaining groups include intra- and extralobar sequestrations as well as malformations of the pulmonary arteries and veins [1-3]. The observed changes were suggestive of purulent cysts or extensive damage to the lung caused by a suppurative process resulting from the lung's malformation.

In the discussed case, we hoped that the decompression of the pleura through drainage would result in rapid clinical and radiological improvement. Since this did not occur, we were forced to intensify our efforts. Thoracotomy was performed and the final diagnosis was made intraoperatively. It should also be noted that it was rather surprising. Before the surgery, we had not expected to find that the empyema was caused by a disintegrating giant lung tumor. This seems particularly strange in the context of the previously conducted diagnostic imaging. However, the final histological diagnosis of hamartoma was an even bigger surprise. In the literature available to us, such a large lesion $(30 \times 25 \mathrm{~cm})$ had never been described. It is also important to mention that the described tumors are considered to be benign. It is hard to agree with such a definition if we consider the complete degradation of the lung in this case. It may be assumed that, as a result of the compression of the bronchi, the initially small lesion led to atelectasis and recurrent inflammation. The developing pulmonary abscesses finally infiltrated the pleura, resulting in pleural empyema.

Hamartoma may originate from different germ layers. Most commonly, cartilaginous tissue is dominant. Hamartoma constitutes $75 \%$ of all benign lung tumors. Pulmonary hamartoma occurs most often between the age of 30 and 60 and is 2-3 times more common in men. In the majority of cases, its course is asymptomatic [4]. According to some authors (Hansen et al.), common symptoms (39\% of cases) include cough, dyspnea, pneumonia, hemoptysis and chest pain [5]. However, judging by the cases we have observed, the disease is mainly clinically silent. The size of hamartoma varies from 1 to $3 \mathrm{~cm}$; in $50 \%$ of cases it is stable in size, while the remaining hamartomas grow $3 \mathrm{~mm}$ per year. It is usually located in the peripheries of the pulmonary parenchyma or in the subpleural region. The incidence of endobronchial hamartoma provided by the literature varies from $1 \%$ to $20 \%$ of cases [6]. The case presented in this article was very different from other described cases, which is the reason why we decided to publish it. 


\section{References}

1. Korlacki W, Dzielicki J. Wady rozwojowe układu oddechowego. In: Chirurgia dziecięca. Czernik J (red.). Wydawnictwo Lekarskie PZWL, Warszawa 2005; 383-385.

2. Stocker JT, Madewell JE, Drake RM. Congenital cystic adenomatoid malformation of the lung. Classification and morphologic spectrum. Hum Pat 1977; 8: 155-171.

3. Stanton M, Davenport M. Management of congenital lesions. Early Hum Dev 2006; 82: 289-295.

4. Whyte RI, Donington JS. Hamartomas of the lung. Semin Thorac Cardiovasc Surg 2003; 15: 301-304.

5. Hansen $\mathrm{CP}$, Holtveg $\mathrm{H}$, Francis D, Rasch L, Bertelsen S. Pulmonary hamartoma. J Thorac Cardiovasc Surg 1992; 104: 674-678.

6. Shields M, Robinson B. Benign tumors of the lung. General Thoracic Surgery 2000; 1515-1519.

7. Hutter J, Reich-Weinberger S, Hutarew G, Stein HJ. Giant pulmonary hamartoma - a rare presentation of a common tumor. Ann Thorac Surg 2006; 82: e5-e7. 